\title{
Analisis Konsep Kawin Hamil pada Film Dua Garis Biru Perspektif Hukum Positif Indonesia dan Hukum Islam
}

\author{
Emiliya Ehsaniyah ${ }^{1}$ \\ ${ }^{1}$ Fakultas Syariah, IAIN Jember. E-mail: sehsaniyah@gmail.com
}

\begin{tabular}{|c|c|}
\hline Article & Abstract \\
\hline $\begin{array}{l}\text { How to cite: } \\
\text { Emiliya Ehsaniyah, } \\
\text { ‘Analisis Konsep Kawin } \\
\text { Hamil pada Film Dua } \\
\text { Garis Biru Perspektif } \\
\text { Hukum Positif Indonesia } \\
\text { dan Hukum Islam’ Vol. } 1 \\
\text { No. } 1 \text { Rechtenstudent } \\
\text { Journal Fakultas Syariah } \\
\text { IAIN Jember. } \\
\text { Histori artikel: } \\
\text { Submit 24 Februari 2020; } \\
\text { Diterima } 4 \text { Maret 2020; } \\
\text { Diterbitkan } 3 \text { April 2020. } \\
\text { ISSN: } \\
\text { 2723-0406 (media cetak) }\end{array}$ & $\begin{array}{l}\text { Nowadays, there are many cases of marriage for pregnant women, this is one of the } \\
\text { effects of too free association between men and women. The phenomenon of } \\
\text { pregnant marriage as a result of promiscuity among adolescents is reflected in the } \\
\text { film Two Blue Lines. In Islamic law, people who engage in husband and wife } \\
\text { relations outside of a legal marriage are punished as adultery. If the adultery results } \\
\text { in pregnancy and marriage, the priests of the Madzhab have different opinions } \\
\text { regarding the validity of the marriage and also the status of the child in the womb. } \\
\text { Whereas in positive law (Marriage Law and KHI), the marriage of a pregnant woman } \\
\text { is legal and the status of the child who is born later is categorized as a legal child. The } \\
\text { purpose of this study was to determine and analyze the concept of pregnant } \\
\text { marriage contained in the scenes of the film Dua Lines Biru to be analyzed using Law } \\
\text { No.1 of } 1974 \text { concerning Marriage, Islamic Law, and Compilation of Islamic Law. } \\
\text { Keywords: Pregnant Marriage, Two Blue Lines Film, Marriage Law, KHI Islamic Law. } \\
\text { Abstrak } \\
\text { Dewasa ini banyak ditemukan kasus pernikahan wanita hamil, hal ini merupakan } \\
\text { salah satu dampak terlalu bebasnya pergaulan diantara pria dan wanita. Fenomena } \\
\text { kawin hamil sebagai akibat pergaulan bebas di kalangan remaja tercermin dalam } \\
\text { film Dua Garis Biru. Dalam Hukum Islam, orang yang melakukan hubungan suami } \\
\text { istri di luar pernikahan yang sah dihukumi zina. Apabila dari hasil perzinahan } \\
\text { tersebut sampai terjadi kehamilan dan dilangsungkan pernikahan maka para imam } \\
\text { Madzhab berbeda perndapat mengenai keabsahan pernikahan itu dan juga status } \\
\text { anak dalam kandungan tersebut. Sedangkan dalam hukum positif (UU Perkawinan } \\
\text { dan KHI) perkawinan wanita hamil tersebut adalah sah dan status anak yang } \\
\text { dilahirkan kelak dikategorikan sebagai anak sah. Tujuan dari penelitian ini adalah } \\
\text { untuk mengetahui dan menganalisis konsep kawin hamil yang terkandung dalam } \\
\text { adegan-adegan film Dua Garis Biru untuk kemudian dianalisis menggunakan UU } \\
\text { No.1 Tahun } 1974 \text { tentang Perkawinan, Hukum Islam dan Kompilasi Hukum Islam. } \\
\text { Kata Kunci: Kawin Hamil, Film Dua Garis Biru, UU Perkawinan, Hukum Islam, KHI. }\end{array}$ \\
\hline
\end{tabular}

\section{Pendahuluan}

Perkawinan merupakan salah satu perbuatan yang disyariatkan Islam yang mengikat pergaulan antara laki-laki dan perempuan yang bukan mahram yang menimbulkan hak dan kewajiban antara keduanya. ${ }^{1}$ Hukum perkawinan telah mengatur tentang tata cara kehidupan dalam keluarga, sebagai komponen pokok dan terkecil dalam kehidupan masyarakat. Kehidupan masyarakat akan terdiri dari keluarga yang dibina dengan baik dan hubungan antar individu yang berjalan harmonis. Ketentuan ini sesuai dengan hakikat manusia sebagai makhluk yang terhormat. Untuk menjaga kehormatan manusia tersebut maka perlu dilakukan pembinaan terhadap hubungan antar manusia dengan baik dan sesuai dengan

${ }^{1}$ Mawardi, Hukum Perkawinan Dalam Islam, (Yogyakarta: BPFE, 1984), 1. 
fitrah dan kedudukannya sebagai manusia. Oleh karena itu, di sinilah pentingnya dilakukan hubungan yang legal untuk menjaga kehormatan manusia. Dalam hal ini, lembaga perkawinan yang bertugas dan bertanggungjawab membentuk hubungan yang legal antar manusia dalam melakukan perkawinan tersebut.

Kendatipun demikian, dalam perkembangan selanjutnya, lembaga perkawinan akan menghadapi tantangan, bahkan bisa terancam eksistensinya ketika dihadapkan pada masalah sosial yang coba mengusik kesakralan institusinya. Salah satu problem tersebut adalah munculnya masalah kehamilan yang terjadi di luar nikah. Problem ini menjadi semakin bertambah rumit ketika dalam kehidupan sosial dewasa ini ternyata kasus ini banyak terjadi di kalangan masyarakat. Permasalahannya sekarang, ternyata dalam kasus ini tidak hanya menyangkut perbuatan zina dari para pelaku dan serta hukuman hudud atas perbuatan mereka, melainkan juga menyangkut status dan nasib hidup bayi yang ada dalam kandungannya.

Dalam konteks ini, maka yang menjadi persoalan adalah mengenai status pelaksanaan perkawinan dalam kondisi hamil tersebut. Terdapat beberapa pendapat dalam menjawab permasalahan tersebut. Imam Syafi'i membolehkan dan menganggap sah perkawinannya. Abu Hanifah juga berpendapat demikian, namun dengan menambahkan persyaratan kebolehan wanita hamil dinikahkan tetapi tidak boleh berhubungan sebelum ia melahirkan. Pendapat sebaliknya diberikan oleh Imam Malik dan Imam Hanbali yang mengharamkan pelaksanaan nikah tersebut. ${ }^{2}$ Dalam Kompilasi Hukum Islam Pasal 53 dijelaskan tentang kebolehan melangsungkan perkawinan bagi perempuan yang hamil di luar nikah dengan pria yang menghamilinya. ${ }^{3}$ Ketentuan dalam KHI tersebut sama sekali tidak menggugurkan status zina bagi pelakunya, meskipun terjadi kehamilan di luar nikah. Memang dalam UU No.1/1974 Pasal 42 tentang perkawinan dan Kompilasi Hukum Islam Pasal 99 menyebutkan bahwa anak yang sah adalah anak yang dilahirkan dalam ikatan perkawinan yang sah. Pada dasarnya dalam Pasal 43 UU No. 1 tahun 1974 Pasal 43 ayat (1) anak yang dilahirkan di luar perkawinan hanya mempunyai hubungan perdata dengan ibunya dan keluarga ibunya. Hal yang sama juga diatur dalam Pasal 100 Kompilasi Hukum Islam disebutkan bahwa anak yang lahir diluar perkawinan hanya mempunyai hubungan nasab dengan ibunya dan keluarga ibunya. ${ }^{4}$

Saat ini di Indonesia perbincangan mengenai fenomena kawin hamil ini kembali ramai diperbincangkan yang mana disebabkan oleh munculnya sebuah film Dua Garis Biru yang ditayangkan pada 11 Juli 2019. Film Dua Garis Biru menceritakan tentang kehidupan sepasang kekasih bernama Bima dan Dara. Keduanya masih duduk di bangku SMA, dan nekat melakukan hubungan seks di luar nikah hingga akhirnya Darapun hamil. Mereka berdua berusaha menutupi kehamilan Dara dan bahkan berniat untuk menggugurkan kandungannya. Setelah kehamilan Dara diketahui oleh keluarga dan pihak sekolah, akhirnya pernikahan keduanya pun dilangsungkan sebagai jalan keluar meski kondisi Dara sedang hamil.

Konsep kawin hamil yang ada di dalam film Dua Garis Biru ini menyimpang dari apa yang menjadi dasar kebolehannya menikahi wanita hamil yang diatur dalam KHI. Tujuan utama dari diperbolehkannya menikahi wanita hamil adalah menyelamatkan masa depan

\footnotetext{
2 A. Zuhdi Muhdlor, Memahami Hukum Islam, (Bandung: al-Bayan, 1995), 58.

${ }^{3}$ Sekretariat Negara RI, Kompilasi Hukum Islam.

${ }^{4}$ Muhdlor, Memahami Hukum, 59.
} 
anak yang dikandungnya agar mendapat hak dan kepastian hukum. Karena pada dasarnya anak yang dilahirkan di luar perkawinan hanya mempunyai hubungan perdata dengan ibunya dan keluarga ibunya (Pasal 43 UUP) Hal yang sama juga diatur dalam KHI bahwa anak yang lahir diluar perkawinan hanya mempunyai hubungan saling mewaris dengan ibunya dan keluarga ibunya (Pasal $186 \mathrm{KHI}$ ). Tentunya hal ini akan menjadi hal yang merugikan bagi anak yang akan dilahirkan.

Sedangkan dalam film Dua Garis Biru kawin hamil dilakukan semata-mata karena telah terjadi kehamilan. Dan kelak anak yang dilahirkan akan diberikan kepada orang lain untuk diadopsi sehingga Bima dan Dara dapat melanjutkan masa depan mereka tanpa terhalangi oleh kehadiran anak yang telah dilahirkan. Meski di akhir cerita Bima berhasil untuk membujuk Dara agar Bima mengasuh anak itu dan Dara tetap mengejar mimpinya kuliah ke luar negeri. Jadi dalam film ini pernikahan kehilangan kesakralannya dan hanya dijadikan sebagai jalan keluar sementara saja. Dan juga tujuan pernikahan yang dilangsungkan bukan lagi untuk membentuk keluarga yang bahagia, kekal, sakinah, mawaddah wa rahmah seperti yang dicita-citakan oleh UUP dan KHI.

Peneliti tertarik untuk mengkaji film karena film merupakan salah satu media masa yang kehadirannya mampu menyampaikan pesan baik itu moral maupun sosial kepada semua halayak serta mempunyai daya persuasif yang mudah diterima oleh masyarakat.

\section{Rumusan Masalah}

Adapun rumusan masalah dalam penelitian ini adalah:

1. Bagaimana konsep kawin hamil dalam film dua garis biru?

2. Bagaimana konsep kawin hamil dalam film dua garis biru menurut tinjauan UU No. 1 Tahun 1974 tentang Perkawinan, Hukum Islam dan Kompilasi Hukum Islam?

\section{Metode Penelitian}

Penelitian ini bersifat penelitian kualitatif deskriptif yang berusaha mendeskripsikan seluruh gejala atau keadaan yang ada, yaitu keadaan gejala menurut apa adanya pada saat penelitian dilakukan. Yang mana berarti dalam penelitian ini, peneliti akan menguraikan secara faktual tentang konsep kawin hamil melalui dialog dan adegan dalam film Dua Garis Biru.

Metode deskriptif bertujuan menggambarkan sifat sesuatu yang tengah berlangsung pada saat riset dilakukan dan memeriksa sebab-sebab dari suatu gejala. ${ }^{5}$ Ada beberapa macam riset yang masuk dalam metode deskriptif, yaitu 1) Studi kasus, 2) Survei, 3) Riset pengembangan, 4) Riset lanjutan, 5) Riset dokumentasi, 6) Riset kecenderungan, 7) Riset kolerasi. Dalam penelitian ini, yang digunakan adalah riset dokumentasi. ${ }^{6}$

Jenis penelitian ini adalah kajian pustaka (library research), yaitu penelitian yang dilaksanakan dengan menggunakan literatur (kepustakaan), baik berupa buku, catatan, maupun laporan hasil penelitian terdahulu. ${ }^{7}$

Sumber data yang digunakan dalam penelitian ini yaitu terdiri atas dua jenis yaitu sumber data primer dan sekunder. Sumber data primer berasal dari pengamatan peneliti terhadap film Dua Garis Biru. Adapun sumber data sekunder bersumber dari dokumen-

${ }^{5}$ Husein Umar, Metode Penelitian untuk Skripsi dan Tesis Bisnis, (Jakarta:PT. Raja Grafindo Persada, 2000), 22. ${ }^{6}$ Husein, 23-25.

7Sangadji, Metodologi Penelitian Pendekatan Praktis dalam Penelitian, 28. 
dokumen berupa catatan, rekaman gambar atau foto, dan hasil-hasil observasi yang berhubungan dengan fokus penelitian, termasuk artikel dan berita media masa di internet yang mendukung informasi terkait film "Dua Garis Biru”. Adapun teknik pengumpulan data pada penelitian ini yaitu dengan cara observasi (pengamatan terhadap tanda pada setiap scene yang memuat nilai kawin hamil dalam film "Dua Garis Biru” dan dokumentasi). 8

\section{Konsep Kawin Hamil dalam Film Dua Garis Biru}

Konsep kawin hamil dalam penelitian ini akan dibagi dalam 4 kategori yaitu a) sebelum pernikahan dimana terjadinya perzinahan hingga menyebabkan Dara hamil, b) dilangsungkannya pernikahan Dara dan Bima, c) Pertemuan Keluarga, ketika Dara dan Bima menemui calon orang tua angkat bayi mereka dan pertemuan keluarga membahas rencana perceraian Dara dan Bima, d) Dara melahirkan.

A. Sebelum Pernikahan

Dara dan Bima yang masih duduk di bangku SMA sedang berpacaran di kamar Dara dan terjadilah perzinahan.

Time Code (04:04) dan (46:52)
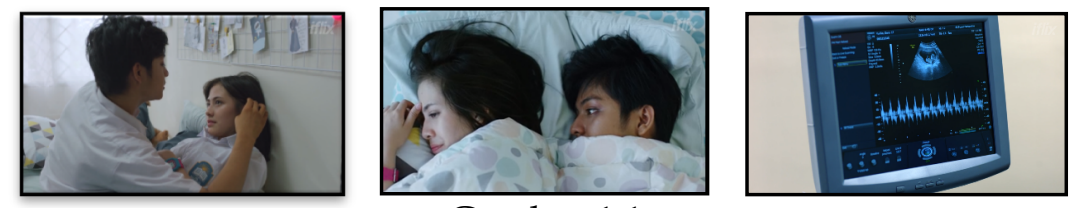

\section{Gambar 1.1}

Dalam adegan ini digambarkan Dara dan Bima yang masih berseragam SMA sedang berpacaran di kamar Dara hingga terjadilah hubungan suami istri di antara keduanya yang menyebabkan Dara hamil seperti yang terlihat dalam gambar pojok kanan yang menunjukkan hasil USG kandungan Dara yang masih kurang dari 3 bulan.

B. Hari Pernikahan

Time Code (1:02:46)

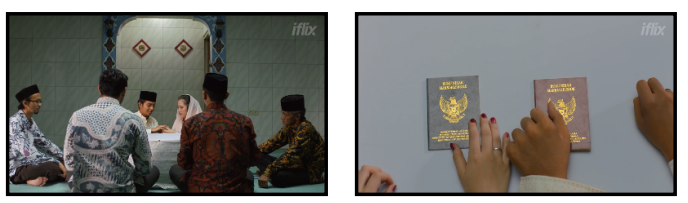

Gambar 1.2

Setelah mengetahui kehamilan Dara, kemudian para keluarga sepakat untuk menikahkan mereka berdua secara sah.

C. Pertemuan Keluarga

Time Code (1:22:47)

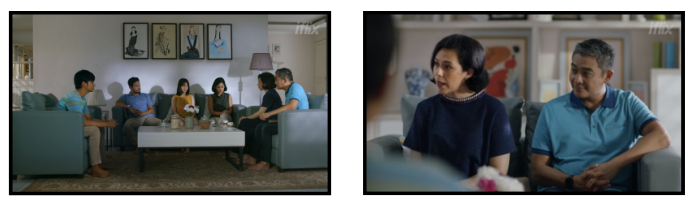

Gambar 1.3

Bima dan keluarga Dara menemui calon orang tua angkat bayi mereka, tante Lia dan om Adi. Dialog:

${ }^{8}$ Tanzeh Ahmad, Metodologi Penelitian Praktis, (Yogyakarta: Teras, 2011), 58. 
Tante Lia: "Tante tu udah berkali kali nyoba program IVF, bayi tabung, tapi ya gagal terus... jadi waktu mama kamu hubungi tante, tante pikir..."

Bima : "Apa saya atau Dara nanti boleh ketemu?"

Om Adi : "Boleh"

Tante Lia : “Cuma mungkin biar gak ribet, gimana kalo nanti anaknya manggil kamu, om dan dara dipanggil tante"

Om Adi : "Atau kakak, senyamannya kalian aja"

Time Code (1:25:15)
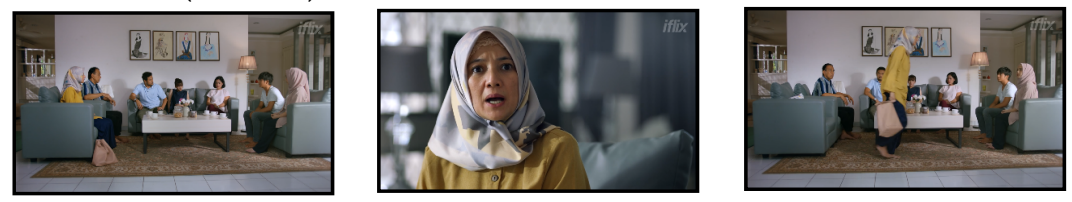

Gambar 1.4

Dalam adegan kali ini, keluarga Dara dan keluarga Bima bertemu untuk membahas rencana perceraian anak mereka nanti di Pengadilan. Namun karena tidak kunjung menemukan titik temu, maka pembahasan tersebut akan dilanjutkan ketika Dara sudah melahirkan nanti. Dialog :

Ayah Dara : "Menurut pengacara kami, pasti nanti dari pihak Pengadilan Agama akan mengusahakan dan bertanya apakah tidak mungkin Dara dan Bima bersatu"

Ibu Dara : "Jawabannya sudah jelas. Tidak mungkin"

Ibu Bima : "Kenapa? Ini kita kok seperti mempermainkan agama ya. Tanggung jawab kita kan bukan cuma di dunia. Di akhirat juga."

Dan juga dalam dialog

Ibu Bima : "Maka dari itu saya tidak mau anak saya berpisah.Tidak mungkin kan mengurus anak seorang diri"

Ibu Dara : "Makanya bayinya harus diserahin. Bima sama Dara ini masih anak-anak kecil. Mana mungkin anak kecil ngurus bayi."

Time Code (1:28:45)
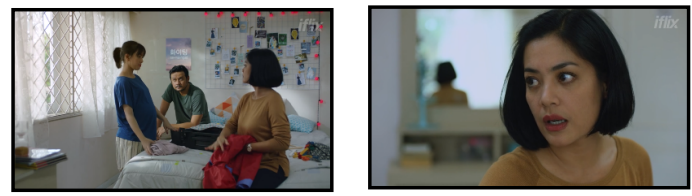

Gambar 1.5

Dara mempersiapkan barang-barang yang akan dibawa ke Korea, ketika papa mengusulkan untuk membeli baju bayi sebagai kenang-kenangan. Ide ini langsung ditolak mama. Dialog:

Mama Dara: "Kan semua rencananya udah jelas, Tante Lia yang siapin semuanya. Kamu lahiran, bayinya dibawa pulang, kita terbang ke Korea."

D. Dara Melahirkan

Time Code (1:43:34)
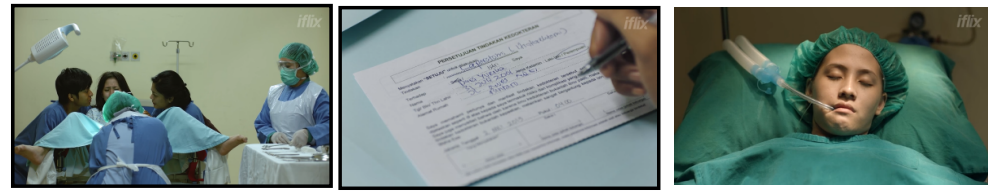

Gambar 1.6 
Dalam adegan ini, Dara berhasil melahirkan secara normal, akan tetapi karena usianya yang masih muda, sehingga badannya belum siap untuk melahirkan, sehingga terjadi pendarahan dan terpaksa dilakukan operasi pengangkatan rahim.

Time Code (1:49:25)
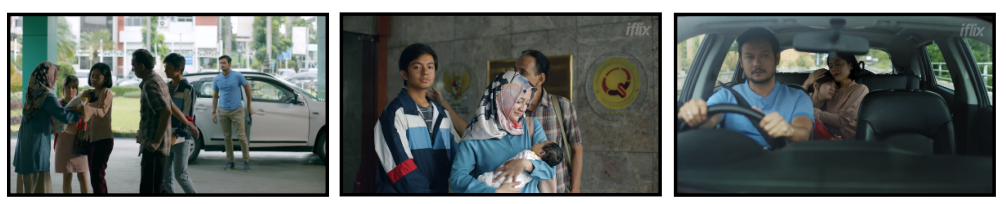

Gambar 1.7

Setelah melahirkan dan Dara diperbolehkan untuk pulang, keluarga Dara dan Bima berpisah di depan rumah sakit, dan bayi yang diberi nama Adam itu tidak jadi diserahkan kepada Tante Lia dan Om Adi, akan tetapi diasuh sendiri oleh keluarga Bima. Sedangkan Dara pulang tanpa membawa bayinya.

\section{Kawin Hamil dalam Film Dua Garis Biru ditinjau dari UU Perkawinan, Hukum Islam dan Kompilasi Hukum Islam}

Kompilasi Hukum Islam yang secara khusus dalam babnya mengatur perkawinan wanita hamil, yaitu Bab VIII Pasal 53 ayat (1), (2), dan (3) di dalamnya ditetapkan bahwa "wanita hamil di luar nikah dapat dinikahi dengan laki-laki yang menghamilinya, tanpa harus menunggu kelahiran anak yang ada dalam kandungannya terlebih dahulu, dan perkawinan pada saat hamil tidak diperlukan lagi perkawinan ulang setelah anak yang dikandungnya lahir". ${ }^{\prime}$

Dengan demikian perkawinan wanita hamil di luar nikah ditetapkan oleh KHI, bahwa wanita hamil di luar nikah dapat dikawinkan dengan pria yang menghamilinya dan dapat ditafsirkan pula "dapat" bahwa wanita hamil dapat pula dikawinkan dengan laki-laki yang bukan menghamilinya.

Dalam hal ini jika dikaitkan dengan kawin hamil yang ada dalam film Dua Garis Biru dimana Dara yang sedang hamil dan kemudian menikah dengan Bima, laki-laki yang memang menghamilinya, maka apa yang mereka lakukan itu sudah sesuai dengan konsep kawin hamil yang diatur dalam KHI Pasal 51 ayat (1) dan (2). Begitu juga jika dilihat dari kacamata hukum Islam, merujuk pada pendapat Imam Syafi'i, Wahbah al-Zuhaili, dan Abu Hanifah yang membolehkan laki-laki manapun untuk menikahi wanita hamil dan laki-laki tersebut halal untuk menyetubuhinya walaupun ia dalam keadaan hamil. Maka dilihat dari sudut pandang KHI maupun Hukum Islam, kawin hamil yang dilakukan oleh Dara dan Bima dalam film Dua Garis Biru adalah sah dan dibenarkan oleh KHI maupun Hukum Islam.

Mengenai ketentuan anak sah, Imam Syafi'i berpendapat bahwa dalam batasan anak sah diharuskan memiliki syarat memiliki masa kandungan 6 bulan dari masa pernikahan. Jadi apabila waktu kelahiran anak hasil kawin hamil tersebut belum mencukupi masa 6 bulan pernikahan, maka anak tersebut tidak bisa dinasabkan kepada suami wanita tersebut. ${ }^{10}$

Jadi berdasarkan uraian pendapat Imam Syafi'i diatas apabila pasangan pelaku zina yang berakibat kehamilan di luar nikah dan menempuh kawin hamil maka sah pernikahan mereka, mengenai keabsahan status anak mereka dapat dikategorikan anak sah apabila anak mereka dilahirkan pada waktu masa pernikahan mereka minimal berusia 6 bulan. Pendapat

\footnotetext{
${ }^{9}$ Departemen Agama RI, Kompilasi Hukum Islam di Indonesia.

${ }^{10}$ Nurul Irfan, Nasab dan Status Anak dalam Hukum Islam, (Jakarta: Amzah, 2012), 34.
} 
ini juga sama dengan pendapat Imam Abu Hanifah yang menyebutkan minimal usia kandungan tersebut adalah 6 bulan dari masa pernikahan. ${ }^{11}$

Dalam film ini Dara melahirkan anaknya dengan jarak 6 bulan dari pernikahan dan kelahiran bayinya. Jarak ini dihitung dari hasil USG pertama kali yang menunjukkan bahwa usia kandungannya masih di bawah 3 bulan (dilihat dari hasil USG pertama Dara), tak lama kemudian Dara menikah dengan Bima. Dara melahirkan bayinya secara normal, dimana usia kehamilan secara normal yakni 9 bulan 10 hari. Jika dihitung dari usia kelahiran bayi yakni 9 bulan 10 hari dikurangi usia kandungan bayi ketika Dara menikah maka diperoleh hasil kurang lebih 6 bulan. Jadi disini bisa ditarik kesimpulan bahwa usia kandungan Dara memenuhi syarat usai kehamilan yang ditentukan oleh jumhur ulama untuk bayi bisa dinasabkan kepada ayahnya.

Jika merujuk pada Pasal 99 Kompilasi Hukum Islam, anak yang ada dalam kandungan Dara sudah dapat dipastikan sebagai anak yang sah. Ini karena anak yang sah menurut Pasal 99 KHI yaitu (a) Anak yang dilahirkan dalam atau akibat perkawinan yang sah, (b) Hasil pembuahan suami istri yang sah di luar rahim dan dilahirkan oleh istri tersebut.

Untuk dapat menganalisa konsep kawin hamil yang ada dalam film Dua Garis Biru jika ditinjau dari hukum positif Indonesia, dimana Undang-Undang yang mengatur tentang Perkawinan di Indonesia yaitu Undang-Undang Nomor 1 Tahun 1974, dan bagi umat muslim ada peraturan lain yang menjadi acuan yaitu Kompilasi Hukum Islam. Menurut Pasal 53 KHI disebutkan bahwa ${ }^{12}$ :

1. Seorang wanita hamil di luar nikah, dapat dikawinkan dengan pria yang menghamilinya.

2. Perkawinan dengan wanita hamil yang disebut pasal ayat (1) dapat dilangsungkan tanpa menunggu lebih dahulu kelahiran anaknya.

3. Dengan dilangsungkannya perkawinan pada saat wanita hamil, tidak diperlukan perkawinan ulang setelah anak yang dikandung lahir.

Dalam aturan tersebut memang secara jelas terdapat unsur kebolehan untuk melakukan perkawinan antara seorang wanita yang sudah hamil dengan seorang laki-laki yang telah menghamilinya.

Menurut Pasal 42 UU Perkawinan disebutkan bahwa anak yang sah adalah anak yang dilahirkan dalam atau sebagai akibat perkawinan yang sah ${ }^{13}$. Sedangkan dalam Pasal 99 KHI terdapat suatu tambahan sedikit tentang status anak yang sah. Pasal 99 KHI berbunyi ${ }^{14}$ :

Anak yang sah adalah:

1. Anak yang dilahirkan dalam atau akibat perkawinan yang sah

2. Hasil pembuahan suami istri yang sah di luar rahim dan dilahirkan oleh istri tersebut.

Jika kita melihat konteks dari bunyi pasal-pasal tersebut kita dapat menyimpulkan, selama seorang anak itu lahir dari perkawinan yang sah, seorang anak akan memperoleh status sebagai anak sah.

Di akhir tahun 2010 lahir Putusan Mahkamah Konstitusi tentang kedudukan anak lahir di luar perkawinan, yang menambah perbendaharaan konstitusi hukum yang merupakan terobosan hukum yang merangkul anak yang lahir di luar perkawinan, memberikan

\footnotetext{
${ }^{11}$ Wahbah al-Zuhayli, al-Fighu al-Islamy wa Adillatuhu, Jilid X (Dimasyq: dar al-Fikr, 1985), 7250.

${ }^{12}$ Departemen Agama RI, Kompilasi Hukum Islam.

13 Sekretariat Negara RI, Undang-Undang No. 1 Tahun 1974 Tentang Perkawinan.

${ }^{14}$ Departemen Agama RI, Kompilasi Hukum Islam.
} 
pendalaman pemahaman konstitusi hukum perkawinan. Dengan demikian adanya peluang revisi khususnya Pasal 43 Undang-Undang Perkawinan. Dengan menambah kalimat adanya pengakuan status hukum terhadap anak yang dilahirkan di luar perkawinan. Disisi lain adanya upaya tidak mengeramatkan Pasal 43 ke arah yang lebih luas jangkauannya, dengan memberikan peluang pengakuan terhadap anak lahir di luar perkawinan, sepanjang dapat dibuktikan berdasarkan ilmu pengetahuan dan teknologi atau alat bukti lain menurut hukum mempunyai hubungan darah, termasuk hubungan perdata dengan keluarga ayahnya. ${ }^{15}$

Adanya Putusan Mahkamah Konstitusi No. 46/PP-VIII/2010 merumuskan Pasal 43 Undang-Undang Nomor 1 Tahun 1974 yang harus dibaca : Anak yang lahir diluar perkawinan hanya mempunyai hubungan perdata dengan ibunya dan keluarga ibunya, serta dengan laki-laki sebagai ayahnya yang dapat dibuktikan berdasarkan ilmu pengetahuan dan teknologi dana tau alat bukti lain menurut hukum mempunyai hubungan darah, termasuk hubungan perdata dengan keluarga ayahnya.

Secara umum pranata hukum dalam hubungan keperdataan dapat meliputi nafakoh, perwalian terhadap harta maupun diri, kewarisan, perwalian dalam perkawinan, larangan perkawinan dan lain-lainnya.

Dari uraian di atas jika kita kaitkan dengan apa yang ada dalam film Dua Garis Biru ini maka perkawinan yang dilakukan oleh Dara dan Bima sah karena sudah sesuai dengan penerapan dalam Pasal 53 KHI ayat (1) dan (2), Pasal 2 ayat (1) dan (2) Undang-Undang No.1 Tahun 1974 tentang Perkawinan. Jika melihat dalam uraian Pasal 42 UU Perkawinan dan Pasal 99 KHI maka status anak yang dilahirkan Dara bisa dikategorikan sebagai anak sah karena dilahirkan dalam perkawinan yang sah.

\section{Kesimpulan}

Konsep kawin hamil yang ada dalam film Dua Garis Biru yaitu pernikahan wanita hamil karena zina. Dimana pernikahan ini diawali oleh kehamilan seorang wanita yang belum menikah karena berzina dengan kekasihnya. Kehamilan yang pada mulanya disembunyikan ini kemudian diketahui oleh keluarga, sehingga keduanya kemudian dikawinkan ketika wanita tersebut masih hamil kurang dari 3 bulan.

Konsep kawin hamil yang diterapkan dalam film Dua Garis Biru adalah sah dan dibolehkan menurut Hukum Islam maupun hukum positif yang berlaku di Indonesia. Dalam film ini Dara menikah dalam keadaan hamil dengan Bima, laki-laki yang memang menghamilinya. Menurut hukum Islam nasab anak yang dilahirkan Dara dinisbatkan kepada ayahnya (Bima) karena jarak perkawinan dan kelahiran bayi mencapai batas minimal 6 bulan. Menurut hukum positif Indonesia, status anak tersebut adalah sah menurut Pasal 42 UU No.1 Tahun 1974 Tentang Perkawinan dan Pasal 99 KHI dilahirkan akibat perkawinan yang sah.

\section{Daftar Pustaka}

\section{Buku}

Ahmad, Tanzeh. 2011. Metodologi Penelitian Praktis. Yogyakarta: Teras.

Irfan, Nurul. 2012. Nasab dan Status Anak dalam Hukum Islam. Jakarta: Amzah.

Kuswarman. 2014. Wali Nikah Anak Yang Lahir Diluar Perkawinan. (Implementasi Keputusan Mahkamah Konstitusi. Surabaya: Garuda Mas Sejahtera.

\footnotetext{
15 Kuswarman, Wali Nikah Anak Yang Lahir Diluar Perkawinan (Implementasi Keputusan Mahkamah Konstitusi) (Surabaya: Garuda Mas Sejahtera, 2014), 15.
} 
Mawardi. 1984. Hukum Perkawinan Dalam Islam. Yogyakarta: BPFE.

Muhdlor, A. Zuhdi. 1995. Memahami Hukum Islam. Bandung: al-Bayan.

Sangadji, Metodologi Penelitian Pendekatan Praktis dalam Penelitian.

Umar, Husein. 2000. Metode Penelitian untuk Skripsi dan Tesis Bisnis". Jakarta: PT. Raja Grafindo Persada.

\section{Perundang-undangan}

Kompilasi Hukum Islam.

Undang-Undang Nomor 1 Tahun 1974 tentang Perkawinan.

Undang-Undang Nomor 23 Tahun 2002 tentang Perlindungan Anak. 